\title{
Bone Marrow Transplantation (BMT) and Gene Replacement Therapy (GRT) In Sickle Cell Anemia
}

\author{
Misaki W \\ Makerere University Faculty of Medicine, Kamala, Uganda
}

\begin{abstract}
Background: Sickle cell anemia (SCA) forms one of the neglected tropical disease of genetic aetiology. Unlike many complex genetic diseases inherited on a multiallelic pattern, SCA is a hemoglobinopathy of Mendelian type genetic inheritance. The SCA trait is inherited through a recessive autosomal link, with the homozygotes(SS) manifesting clinical disease, while the heterozygoste(AS) are clinically normal-exept in states of hypoxia or severe infection.
\end{abstract}

Method: Review of relevant literature on bone marrow transplantation and gene replacement therapy in sickle cell anaemia was obtained from texts and Pubmed search.

Results: The exact genetic disorder assailing SCA is the production of mutant or abnormal $\beta$ peptide chains in which the amino acid Glutamine has been substituted with valine. The issuing Haemoglobin polymerizes when deoxygenated,causing constituent RBCs to sickle, haemolyse and block small blood vessels- a clinical state that manifests as haemolytic anemia, aplasia, thrombo-embolic phenomenon, or painful crises. Unfortunately, up to day, there is no cure to SCA, and management only aims at preventing or ameliorating attacks.

Conclusion: By virtue of its well defined and localized genetic aetiopathophysiology, and the advances in gene replacement therapy and regenerative medicine, we argue here the case for Bone marrow transplantation (BMT) and Gene replacement therapy (GRT) in sickle cell anemia

Key words: Sickle cell anemia, Gene replacement therapy, Bone marrow Transplantation, Regenerative Medicine

\section{Date accepted for publication $12^{\text {th }}$ June 2008 \\ Nig J Med 2008; 251 - 256 \\ Copyright $\odot 2008$ Nigerian Journal of Medicine}

\section{Introduction}

The current global distribution of resources geared towards research and improvement of health within the tropics has been heavily skewed and biased by the burden of the "big three" infectious diseases, viz. malaria, Tuberculosis and HIV infectious diseases ${ }^{1,2}$, a policy that has left other diseases here termed the Neglected Tropical Diseases(NTDs). In this article, we try to point out that Sickle Cell anemia (SCA)-though being of non-infectious etiology, is one of the neglected tropical diseases by highlighting its burden and distribution, pathophysiology and clinical impacts on the quality of life for its victims, and more significantly, the available but neglected opportunity for developing an effective cure ${ }^{3-11}$.

\section{Analysis \\ Background}

Sickle Cell Anemia (SCA) is a genetically inherited disease marked by a disorder in the molecular structure of the oxygen carrying molecule called hemoglobin ${ }^{12-16}$. Together with Thalassemia ${ }^{17-19}$, these groups of disorders are called hemoglobinopathies. Sickle Cell Anemia represents one of those non-infectious tropical diseases that enormously affects the quality of Life of many young natives within the tropics in terms of frequent hospitalizations, and to the worst claims prematurely its victims' lives ${ }^{7-11}$. None the less, in the wake of the advancements in genomics related research ${ }^{20-24}$, SCA also represents one of those diseases in which a cure is readily feasible, and one that's worth of focused research geared.

\section{Global burden and distribution of Sickle Cell Disease}

The $59^{\text {th }}$ World Health Assembly in May 2006 estimated that about $5 \%$ of the world's population is affected by the sickle cell trait, and that $25 \%$ of them were carriers of the non-clinical recessive trait ${ }^{24}$. On average, each year, about 300,000 babies are born with the clinical trait worldwide, with majority of these cases occurring in low and middle income countries (see figure 1). All hemoglobinopathies are more prevalent in the tropics, although population migration has lead to cases in both Europe and North America ${ }^{1-11,17-19,24}$. In particular, the SCA trait predominates in Africa, with BlackAfricans and their worldwide descendants being most affected. The

Correspondences to Wayengera Misaki E mail wmisaki@yahoo.com +256782450610 
distribution of the burden of SCA along the malaria belt within Africa, and the associated protection from plasmodium falciparum, the protozoa that causes malaria has made many clinicians to hypothesize that the evolution of the SCA trait in humans was in response to genetic adaptation to render its carriers immune to malaria. ${ }^{24}$

\section{Figure I. Global Distribution of Sickle cells Anemia and other Hemoglobinopathies.}

It is estimated that each year over 300 ,

- Approximately $5 \%$ of the world's population are carriers of a trait gene for sickle-cell disease or thalassaemia; The percentage of people who are carriers of the gene is as high as $25 \%$ in some regions.

- These conditions are most 000 babies with severe forms of these diseases are born worldwide; the majority in low and middle income countries. prevalent in tropical regions; however population migration has spread these diseases to most countries.

- Thalassaemias are the most common in Asia, the Mediterranean basin, and the Middle East.

- Sickle-cell disease predominates in Africa.

Source: WHO fact sheets. Sickle-cell disease and other hemoglobin disorders. Http://www.who.int/mediacentre/factsheets/fs308/en/index.html

\section{Pathophysiology and clinical consequences of sickle cell disease}

SCA is due to production of an abnormal or mutant Beta $(\beta)$ peptide chain of the Hemoglobin molecule, the main carrier of oxygen within the Red Blood cells. In SCA, an amino acid substitution occurs in the gene coding for the $\beta$ peptide, with glutamine being replaced by Valine (Glu? Val) at position $6^{12-16}$. This results in the production of $\mathrm{HbS}$ rather than $\mathrm{HbA}$ (or $\mathrm{HbF}$ in case of the newly born or fetuses) $)^{1-11}$. The inheritance of the SCA trait, unlike for many multi-allelic disorders, follows a typical Mendelian style on an autosomal recessive basis, with the homozygotes(SS) having $\mathrm{SCA}(\mathrm{HbSS})$ and the heterozygotes(HbAS) carrying the trait but no manifestation of the clinical diseases except in cases of severe hypoxia. Individuals with the later pattern (carriers) have also been observed to be resistant to Malaria. Symptomatic SCA disease may occur in carriers of the sickle cell trait if genes coding other amino acid substitutions occur concurrently ( $\mathrm{HbCS}$, and $\mathrm{HbDS}$ ). For the homozygotes(HbSS), in circumstances of low oxygen or deoxygenation(such as infection, exercise, anaethesia, exposure to high altitude, cold or dehydartion), the abnormal hemoglobin polymerizes to form fibres that cause the RBCs to change shape from the normal smooth doughnut shape to a cresecent or half moon shape(sickling). These issuing sickle cells are fragile, easily aggregate on each other (sticky) and block small vessels and hemolyse readily. This results in the clinical manifestations seen in $\mathrm{SCA}^{3-11}$ :
1. Haemolytic anemia $(\mathrm{Hb}<6-8 \mathrm{~d} / \mathrm{dl})$

2. Thromboembolic phenomen(which may lead to end organ infarction:Femoral head necrosis, hyposplennism secondary to infarction, strock)

3. Sequestration(trapping of RBCs in the liver and spleen with subsequent enlargement)

4. Aplasia(decreased bone marrow activity)

Early clinical manifestations of SCA range from anemia with jaundice, painful swelling of hands and feet (hand and foot syndrome), splenomegaly if <10years (infarction reduces spleen size with increasing attacks). Young sicklers alternate periods of good health and acute crises that keep them frequently hospitalized with drastic impacts on their quality of life. In severe chronic cases, renal failure may occur, bone necrosis (femoral head commonest), osteomylitis, leg ulcers due to infarction, and iron overload from repeated therapeutic blood transfusions. Long term lung complications include hypoventilation, atelectasis, and infiltrates. CVS accidents (stroke) may also occur too $0^{3-11}$.

The heaviest burden of SCA within the tropics comes from undiagnosed cases in childhood(in which case, admission due to SCA related illnesses account for 20$30 \%$ of all pediatric emergency admissions), or adult females who become pregnant. This has prompted many health systems to include genetic counseling and screening for the SCA trait as one of the antennal routine tests.

\section{Current treatment options for sickle cell disease}

Although several supportive management interventions are available for SCA (figure 2), there is currently no cure for SCA. The Current consensus thus centers on the reduction of the burden of SCA, and maintains that the most cost-effective strategy doing so is to complement disease management with prevention programmes. Inexpensive and reliable blood tests can identify couples at risk for having affected children. This genetic screening is especially opportune before marriage or pregnancy, allowing couples to discuss the health of their family. Subsequent genetic counselling informs trait carriers of risks that may be passed along to their children and the treatment needed, if affected by a haemoglobin disorder. Prenatal screening of genetic diseases raises specific ethical, legal and social issues that require appropriate consideration ${ }^{19}$. Health Canada, has moved to include screening for the SCA trait in all pregnant mothers with a suggestive sociofamily history for SCA. 
Figure 2. Available supportive interventions for SCA

- High fluid intake

- $\quad$ Healthy diet

- $\quad$ Folic acid supplementation

- $\quad$ Pain medication

- Antibiotics for infections (both prophylactic and therapeutic

- Immunization against encapsulated organisms

- Prophylactic and therapeutic antimalarials

- Blood transfusions if $\mathrm{HB}<6 \mathrm{mg} / \mathrm{dl}$

Hydroxyuria(increase production of fetal hemoglobin and decreases fibre production via $\mathrm{HB}$ polymerization, with $50 \%$ decrease in attacks)

\section{Discussion}

Current analysis, global research interest and its loopholes as regards diseases like SCA

The above analysis serves to define SCA as a major cause of debilitation and mortality among its victims within the tropics that is still incurable, and has widely been neglected by both clinical and basic science research in terms of the search for a cure ${ }^{1-25}$. As for many diseases that affect developing countries in the tropics, many large pharmaceutical have no much interest in searching for a cure for SCA simply because the returns in terms of profits are prospectively minimal. This leaves the onus of innovation and research geared towards the search for cures for diseases such as SCA mainly to the basic scientists within the tropics. However, a lack of facilities, specialty skills and in many cases funds renders such efforts fruitless. The Consequence is that young researchers and clinicians that may have taken a central role towards the discovery of cures for diseases such as SCA find greener pastures elsewhere in other fields of graduate studies.

The WHO along with its global partners in health has of late however renewed efforts aimed at addressing the "neglected diseases of the tropics ${ }^{25}$. In particular, the governing bodies of the World Health Organization have adopted two resolutions on haemoglobin disorders. The resolution on Sickle-Cell Disease from the 59th World Health Assembly in May 2006 and the Resolution on Thalassaemia from the 118th meeting of the WHO Executive Board call upon affected countries and the secretariat of WHO to strengthen their response to these conditions $^{19}$. Specifically, WHO will:

- Increase awareness of the international community of the global burden of these disorders;

- Promote equitable access to health services;
- $\quad$ Provide technical support to countries for the prevention and management of these disorders; and

- $\quad$ Promote and support research to improve quality of life for those affected.

We see this as an opportunity for researchers in the tropics to embark on projects geared towards getting cures to several NTDs such as SCA.

The window of hope: a gene therapy for sickle cell anemia?

Although regenerative medical interventions for thalassemias have been documented to yield curative results ${ }^{17-19}$, the use of this approach in related research and search for a cure to SCA is widely lacking. The identification of the 10 most vital areas in which genomics research can improve the health of populations living in the developing world by the Genomics working group of the UN emphasizes the need for research in this direction ${ }^{20-24}$. The indicated partners above may play a further central role in harnessing incentives for the training of more specialists from the tropics in the areas of genomics and regenerative Medicine using the SCAmodel.

By virtue of its well defined genetic pathophysiology ${ }^{12-16}$, we envision a cure to SCA through regenerative medicine strategies as a certainly attainable goal. The spectrum of approaches for achieving this can be broadly divided into two:

\section{A. Bone marrow transplantation(BMT)}

Bone marrow transplantation is the process of donating the blood manufacturing machinery that is abundant in the marrow of bone to a needy recipient. The donation may come from self (say as occurs prior to chemotherapy-in which case the marrow tissue is labeled autograft) or it may be from another health individual of the same species, and Human Leukocyte antigen (HLA) match ( also know as allograft or genetically identical transplants). Heroic maneuvers have even attempted transplantation with cross species' tissue (zenografts) ${ }^{26}$. BMT has become a major standard of care in other hematological disorders such as Leukemia's and Mylodisplasias ${ }^{27}$, offering both cure and improved quality of life for both young and older patients and twin and non-twin matches ${ }^{27-31}$. Perhaps the greatest challenge with BMT as a therapeutic strategy for SCA is the lack facilities for HLA sub- typing within the tropics. Further still, it would be necessary to develop further antigen antibody (Ag-AB) paradigms for 
red blood cells. BM transplantation for SCA however derives a great case in the fact that SCA is a prenatally diagnosable genetic disease, offering the chance for treatment in infancy when the immune system is not very sensitized the same reasons why several BM grafts done for leukemia take in infancy more that in adulthood ${ }^{27-29}$. Further still, the social- ethical controversy may be little easier to overcome, given that many of this children and their families are accustomed to blood transfusions.

\section{B. Gene replacement therapy(GRT)}

Gene replacement is the process by which, a defective gene for which reason a disease is occurring, is replaced in the diseases person. There are essentially 2 strategies for gene replacement therapy-the ex-vivo (in which case a patients committed cell line to the disease cells are manipulated outside of the body to replace the defective gene, and then transplanted back into the patient-a form of recombinant allografting) or in-vivo (where special vectors-mainly recombinant viruses; are used to shuttle the gene of interest to the defective cells inside the patient) ${ }^{30}$. The latter approach is becoming increasingly common for immune reconstitution, and the technology is well developed ${ }^{32-34}$, making its transfer for use in SCA easy. The challenge here is that special erythrotropic viral vectors have to be developed. Adenoviruses such as the Adeno-associated virus serotype 4 (AAV4) have been shown to have this potential ${ }^{35}$, with recombinant adenoassociated virus (rAAV) vectors containing the galactosidase (AAV-lacZ) gene being shown for instance to eefectively transducer adult BALB/c mice muscles cells with the protein of interest expression lasting at least 32 weeks in myofibers ${ }^{36}$. In addition, regulatory proteins and pathways for globin-molecule synthesis are more elucidated today ${ }^{16-18}$, with both the messenger RNA

\section{References}

1. WHO. Removing obstacles to health development. Geneva; WHO: 1999.

2. UNAIDS. Report on the global HIV-AIDS epidemic July 2006.

3. Au WY, Leung WC. Challenges and pitfalls in prenatal screening in pregnancies involving allogeneic stem cell transplantation recipients.Bone Marrow Transplant. 2007; 39(7):379-82.

4. Gambero S., Canalli AA, Tiana F., et al Therapy with hydroxyurea is associated with reduced adhesion molecule gene and protein expression in sickle red cells with a concomitant reduction in adhesive properties. Eur J Haematol. 2007; 78(2):144-51.

5. Kehindi KO, Olaniyi, JA, Fakunle EE. Case report: extra pulmonary tuberculosis in sickle cell disease. Afr J Med Med Sci. $\quad 2006 \quad ; 35(3): 381-4$. McClain BC, Kain ZN Pediatric palliative care: a novel approach to children with sickle cell disease.Pediatrics. 2007 ;119(3):612-4.
(ACCESSION M25079) and complementary DNA (ACCESSION V00499) for the human beta globin readily available ${ }^{37,}{ }^{30}$. Morever, the successful completion of the 13-year project coordinated by the U.S. Department of Energy and the National Institutes of Health in 2003, the Human Genome Project $(\mathrm{HGP})^{39,40}$ has availed us with several novel insights in gene regulation and gene replacement therapy that make the success of regenerative approaches for SCA all the more likely to succeed. Perhaps the greatest case for gene replacement therapy in SCA comes from the great success that both BMT and GRT have scored in Severe combine Immunodeficiency (SCID), a genetic disorder caused by mutations in the common gamma chain (gammac- a shared component of the interleukin (IL)-2, IL-4, IL-7, IL-9, IL-15, and IL-21 receptors) and characterized by lack of cellular and humoral immunity $^{4143}$.

\section{Recommendations}

Amidst the rapid ongoing developments in the areas of regenerative medicine and stem cell research ${ }^{44,45}$, it is imperative that the global community strives to ensure that the already achieved breakthroughs are maximally harnessed for the better health of all ${ }^{21-25}$. A focus on overcoming the ethical, equity and Legal and social challenges is one side of the coin, the other side lines in ensuring appropriate skill and technology transfer in cases such as SCA.

In conclusion, we call upon basic researchers and clinicians in the tropics along with their partners in development, within and without the tropics to use this window of hope and mobilize resources towards harnessing regenerative medicine the tropics neglected diseases such as SCA.

6. Adjaoud D Physiopathology and treatment of sickle cell $\begin{array}{llllll}a & n & e & m & i & a\end{array}$ Soins Pediatr Pueric. 2007 ; (234):16-8.

7. Gervaise S Living with sickle cell anemia. A painful disease. Soins Pediatr Pueric. 2007 ;(234):15.

8. Fournier- Charriere E. Vaso-occlusive pain crises in children with sickle cell anemia] Soins Pediatr Pueric. 2007 ; 234):21-6.

9. Cavazza F, Perrin A. Care of children with sickle cell anemia in the health community] Soins Pediatr Pueric. 2007 ; (234):27-31.

10. Ellison, AM., Bauchner, H. Socioeconomic status and length of hospital stay in children with vaso-occlusive crises of s i ckle c e l l dise a s e. J Natl Med Assoc. 2007 ;99(3):192-6.

11. Agenet, J. Sickle cell anemia and social vulnerability, an accumulation of handicaps Soins Pediatr Pueric. 2007 Feb;(234):34-6. 
12. Lawn R.M., Efstratiadis A., O'Connell C., Maniatis T. The nucleotide sequence of the human beta-globin gene. Cell 1980; 21:647-651.

13. Wood ET., Stover DA., Slatkin M., Nachman MW., Hammer MF.The beta-globin recombinational hotspot reduces the effects of strong selection around $\mathrm{HbC}$, a recently arisen mutation providing resistance to malaria. Am. J. Hum. Genet. 2005; 77:637-642

14. Braunitzer G., Gehring-Muller R., Hilschmann N., Hilse K., Hobom G., Rudloff V., Wittmann-Liebold B."The constitution of normal adult human haemoglobin." ; Hoppe-Seyler's Z. Physiol. Chem. 1961; 325:283-286

15. Finch J.T., Perutz F., Bertles J.F., Doebler J. Structure of sickled erythrocytes and of sickle-cell hemoglobin fibers.Proc. Natl. Acad. Sci. U.S.A. 1973; 70:718-722.

16. Wishner B.C., Ward K.B., Lattman E.E., Love W.E.Crystal structure of sickle-cell deoxyhemoglobin at $5 \mathrm{~A}$ resolution.J. Mol. Biol. (1975;98:179-194

17. Thein S.L., Hesketh C., Taylor P., Temperley I.J., Hutchinson R.M., Old J.M., Wood W.G., Clegg J.B., Weatherall D.J. Molecular basis for dominantly inherited inclusion body betathalassemia. Proc. Natl. Acad. Sci. U.S.A. 1990; 87:39243928.

18. Murru S., Poddie D., Sciarratta G.V., Agosti S., Baffico M., Melevendi C., Pirastu M., Cao A. A novel beta-globin structural mutant, Hb Brescia (beta 114 Leu-Pro), causing a severe betathalassemia intermedia phenotype. Hum. Mutat. 1992; 1:124128.

19. de Castro C.M., Devlin B., Fleenor D.E., Lee M.E., Kaufman R.E. A novel beta-globin mutation, beta Durham-NC [beta 114 Leu-->Pro], produces a dominant thalassemia-like phenotype. Blood. 1994; 83:1109-1116.

20. UN Development Programme(2001) Human development report. http://www.undp.org/hdr2001/completenew.pdf. Accessed 28th March 2007

21. UN Millenium Project (2005) Innovation: Applying knowledge in development. Task force on science, technology and

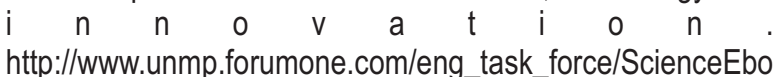
ok.pdf. Accessed 28th March 2007

22. Heather L.Greenwood, Peter A. Singer, Gregory P. Downey, Douglas K. Martin, Halla Thorsteindottir,Abdallah S. Daar. Regenerative Medicine and the developing world. PLoS 2006; 3(9): e381. DOI: 10.1371/journal

23. Fabio Salamanca-Buentello,Deepa L. Persad,Erin B.Court, Douglas K. Martin, Abdallah S. Daar, Peter A. Singer. Nanotechnology and the developing world. PLoS 2005; 2(4): e97.DOI: 10.1371/journal

24. Singer P.A, Bhatt A, Frew S, Greenwood H, Persad DL, Salamanca-Buentello F, Seguin B, et al. The critical role of genomics in global health. Global Forum update on Research for Health 2005Aug; 2:113-117

25. WHO fact sheets. Sickle-cell disease and other hemoglobin

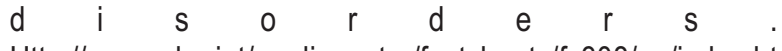
Http://www.who.int/mediacentre/factsheets/fs308/en/index.ht ml accessed 1 April 2007

26. Wuest D.Transfusion and stem cell support in cancer treatment. Hematology/Oncology Clinics of North America, 1996,10(2)397-429

27. Horowitz MM, Gale RP, Sondel PM, et al. Graft-versusleukemia reactions after bone marrow transplantation. Blood. 1990;75(3):555-62
28. Hessner MJ, Endean DJ, Casper JT, et al. Use of unrelated marrow grafts compensates for reduced graft-versusleukemia reactivity after T-cell-depleted allogeneic marrow transplantation for chronic myelogenous leukemia. Blood. $1995 ; 86(10): 3987-96$

29. Drobyski WR, Pelz C, Kabler-Babbitt C, Hessner M, BaxterLowe LA, Keever-Taylor CA. Successful unrelated marrow transplantation for patients over the age of 40 with chronic myelogenous leukemia Biol Blood Marrow Transplant. 1998;4(1):3-12

30. Spencer A, Szydlo RM, Brookes PA, et al . Bone marrow transplantation for chronic myeloid leukemia with volunteer unrelated donors using ex vivo or in vivo T-cell depletion: major prognostic impact of HLA class I identity between donor and recipient Blood. $1995 ; 86(9): 3590-7$

31. Drobyski WR, Ash RC, Casper JT, et al. Effect of T-cell depletion as graft-versus-host disease prophylaxis on engraftment, relapse, and disease-free survival in unrelated marrow transplantation for chronic myelogenous leukemia Blood. 1994 ;83(7):1980-7

32. Naldini L, Blömer U, Gallay P, et al. In vivo gene delivery and stable transduction of nondividing cells by a lentiviral vector Science. 1996 ;272(5259):263-7

33. Chang LJ, Urlacher V, Iwakuma T, Cui Y, Zucali J Efficacy and safety analyses of a recombinant human immunodeficiency virus type 1 derived vector system Gene Ther. 1999;6(5):715-28

34. Douglas JL, Lin WY, Panis ML, Veres G. Efficient human immunodeficiency virus-based vector transduction of unstimulated human mobilized peripheral blood CD34+ cells in the SCID-hu Thy/Liv model of human T cell lymphopoiesis. Hum Gene Ther. 2001;12(4):401-13

35. Kaludov N, Brown KE, Walters RW, Zabner J, Chiorini JA. Adeno-associated virus serotype 4 (AAV4) and AAV5 both require sialic acid binding for hemagglutination and efficient transduction but differ in sialic acid linkage specificity. J Virol. 2001;75(15):6884-93

36. Kessler PD, Podsakoff GM, Chen X, et al. Gene delivery to skeletal muscle results in sustained expression and systemic delivery of a therapeutic protein. Proc Natl Acad Sci USA. 1996;93(24):14082-7

37. Marotta,C.A., Forget,B.G., Cohen-Solal,M. and Weissman,S.M. Nucleotide sequence analysis of coding and noncoding regions of human beta-globin mRNAProg. Nucleic Acid Res. Mol. Biol. 1976; 19, 165-175

38. Lawn,R.M., Efstratiadis,A., O'Connell,C. and Maniatis,T. The nucleotide sequence of the human beta-globin gene. Cell 1980;21(3), 647-651

39. Venter JC, Adams MD, Myers EW, et al. The Sequence of the Human GenomeScience. 2001;291(5507):1304-51

40. International Human Genome Sequencing Consortium. Finishing the euchromatic sequence of the human genome. Nature. 2004 Oct 21;431(7011):931-45

41. Puck JM. Severe combined immunodeficiency: new advances in diagnosis and treatmentImmunol Res. 2007;38(1-3):64-7

42. Otsu M, Candotti F. Gene therapy in infants with severe combined immunodeficiencyBioDrugs. 2002;16(4):229-39.

43. Hartnett BJ, Yao D, Suter SE, et al. Transplantation of Xlinked severe combined immunodeficient dogs with CD34+ bone marrow cellsBiol Blood Marrow Transplant. 2002;8(4):188-97. 
44. Yu, J, Vodyanik MA., Smuga-Otto K. , et al Induced Pluripotent Stem Cell Lines Derived from Human Somatic Cells. Published online November 20 2007; 10.1126/science.1151526
45. Takahashi K, Tanabe K, Ohnuki K, et al Induction of Pluripotent Stem Cells from Adult Human Fibroblasts by Defined Factors. Published online November 162007. DOI:10.1016/j.cell.2007.11.019 